\title{
Serum Response Factor
}

National Cancer Institute

\section{Source}

National Cancer Institute. Serum Response Factor. NCI Thesaurus. Code C91799.

Serum response factor (508 aa, $\sim 52 \mathrm{kDa}$ ) is encoded by the human SRF gene. This protein is involved in the modulation of transcription, cell proliferation and cardiac morphogenesis. 